\title{
A DIETETIC APPROACH TO THE COELIAC AFFECTION
}

\author{
BY \\ W. G. WYLLIE, W. W. PAYNE, and D. W. BEYNON \\ From The Hospital for Sick Children, Great Ormond Street, London
}

(Received for Publication february 8, 1950)

The coeliac affection occurs among children of all financial grades of the population, making its appearance some time between the ninth month of life and the end of the second year. Its incidence has been on the increase since before 1939, partly, no doubt, due to a more frequent recognition of its features. The war cannot be entirely blamed as, both during hostilities and since, food rationing has provided a better balanced diet in many homes, and more intense propaganda on food values has been provided by child welfare clinics.

The traditional method of treatment, concentrating on reduced fat intake, was unsatisfactory, leading by a lengthy and laborious progress to an often imperfect recovery. Some improvement in results followed the high vitamin B therapy of May, McCreary, and Blackfan (1942), but there was still a large residuum of complete or partial failures and of recurrences. It was decided, therefore, during the war, to investigate the treatment advocated by Bircher-Benner (1935) who, in his Zurich clinic, had obtained good results with a fruit and vegetable diet. A case of coeliac disease, first diagnosed at 3 years of age, had been placed on this diet at the age of 6 years, and gained $14 \mathrm{lb}$. in eight months with an increase in height of three inches. Similar, though modified, treatment had been introduced by Feer (1929) at the Kinderklinik, Zurich, and later continued by his successor, Fanconi. Fanconi (1930) referred to favourable results in $\mathbf{5 0}$ typical cases of coeliac disease treated with the fruit and vegetable diet.

The present report describes the treatment of 25 cases of coeliac disease. The first 19 of these were given the fruit and vegetable diet advocated by Bircher-Benner (Bircher-Benner diet).* At first this diet was followed exactly, but with the passage of time disadvantages became evident and eventually only nine cases continued on the strict regime. The diet of four cases had to be modified by the addition of appreciable amounts of protein, and two cases relapsed and died. Gradually a new diet was evolved, being a modification of that used by

\footnotetext{
This was prepared under the direction of Mrs. C. Loewenfeld.
}

Fanconi. Four cases not responding well to the Bircher-Benner diet were changed on to this, and then a further six fresh cases were treated immediately on diagnosis.

The diagnostic criteria used for the cases in this therapeutic trial were those given by May (in Garrod, Batten, and Thursfield 1947): (1) onset of symptoms six months or later after birth; (2) characteristic pultaceous, putty-coloured faeces; (3) anorexia and failure to gain, or actual loss, in weight, and wasting of muscles; (4) distension of abdomen; (5) impaired absorption of fat; (6) blood sugar rise of less than $40 \mathrm{mg}$. \% in the oral glucose tolerance test ; (7) normal trypsin enzyme content of pancreatic secretion; (8) no evidence of chronic infection, anomaly of intestines, parasitic infestation, or fibrocystic disease of the pancreas.

All cases fulfilled these criteria except that in the? first seven, which had been unsuccessfully treated previously, the laboratory investigations were not quite complete.

The criteria of progress adopted were: return of appetite; improvement in the nature of the stools; reduction in girth; increase in weight and height; maintenance of normal level of haemoglobin and protein in the blood.

There are other changes which are obvious to the nurses and physicians, such as greater happiness and contentment, and the healthier appearance of the child as shown by the improved texture of skin and hair and increase of muscular tone. These factors, not being susceptible of measurement, have not been used in assessing progress.

\section{The Bircher-Benner Diet}

Briefly this diet consists of a preliminary short period of three to six days in which only raw fruit and vegetable juices are given. Then, in stages, nutmilk (diluted nutcream); fruit, grated or as puree; raw fruit porridge (Muesli), grated vegetables, and a cooked vegetable soup with added soya fiour are given. Next salads of shredded or grated root vegetables, shredded fruit, and leaf vegetables and cooked vegetables either in soup or as 
a puree are added. The diet is alternated with three days of only raw food and three days with added cooked foods with a transition day between. Honey is given almost from the start, and as soon as nutmilk is given 'enervyte, a wheat germ concentrate containing the vitamin B complex, is added. Later further additions are made such as cream cheese, stewed fruit, rusks, wholemeal bread with a little butter, potatoes, macaroni, egg (once a week), and a little meat twice a week. Each addition is made separately-at first in small and then in gradually increasing quantities - the effect on the stools, appetite, and general condition being the guide. Finally the number of 'raw days' is reduced to one or two a week.

It will be seen that to start with the diet consists only of soluble proteins, carbohydrates, and salts. The early addition of nutcream increases the calorie intake by adding fat and protein. Until this stage has been reached the calorie intake is deficient, as also is the protein. In the final stages of the diet the calorie and protein intake is adequate, but the calcium is lower than in the average diet. The vitamin $\mathrm{D}$ content is also low, and in the usual absence of adequate sunlight regular exposure to ultra-violet light is needed.

Nineteen cases were treated initially with this diet, and the records of their gain in height and weight compared with the expected gains are shown in Figs. 1-19. After a stay in hospital on the diet, varying between three months and two years, the children were sent home or to a suitable convalescent home. The length of stay varied owing to a variety of reasons. In general, each child was sent home when fully established on the diet, but because of the war some children could not be found suitable homes and their stay was prolonged. In other cases intercurrent infections caused setbacks. Many cases returned for a further period of treatment, usually because of failure to maintain the diet at home.

\section{Results of Treatment}

The result of the treatment can be divided into three phases: (1) immediate, the first few weeks; (2) intermediate, the succeeding months in hospital; (3) late, the fate of the children on leaving hospital.

Progress was regarded as good only if the rates of increase of height and weight equalled those expected for the age.

Immediate Phase. In the first few weeks there was in all cases a considerable loss of weight of between $\frac{1}{2}$ and $2 \frac{1}{2} \mathrm{lb}$., with a reduction of girth and a marked improvement in the stools. The general condition of the child sometimes deteriorated, and gave rise to some anxiety in a few cases which were in a poor condition to start with. The rapid loss of weight appeared to be due to two factors, the partial starvation and the decrease in the large mass of fermenting intestinal contents, as shown by the stools changing from pale, loose, and bulky, to dark brown, firm, and small. It was considered that much of the immediate improvement was due to the relief of the distension.

Intermediate Phase. A feature of this phase was a marked fall in plasma protein levels-to $4^{\circ}$ or less, often with oedema. This occurred in nine cases, and in most of them necessitated plasma transfusion. The haemoglobin at the beginning of treatment was under $80^{\circ}$ o in all but three cases. Under treatment it fell further in four cases and subsequently rose again, but in only ten did it finally exceed $80^{\circ}$. No case of severe anaemia or megalocytic anaemia occurred.

Late Phase. This phase, at home, was, as was to be expected, often not so successful as in hospital, particularly as in the last years of the war and the first post-war years when this part of the work was being done special diets were difficult to obtain and were expensive. Relapses occurred, sometimes with oedema or low plasma protein levels. Slight clinical rickets was observed once in this phase and one other patient had a raised plasma phosphatase level.

TABLE 1

Results of Bircher-BenNer Diet

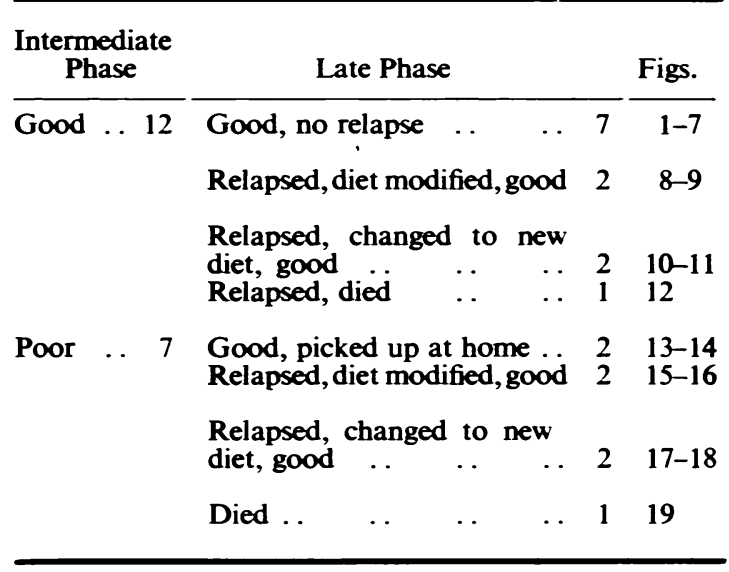

Summary of Final Results

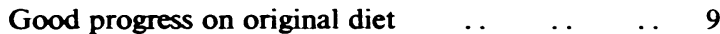
Good progress after modification of diet by increase $\begin{array}{llllll}\text { of protein } & \ldots & \ldots & \ldots & \ldots & \ldots\end{array}$ Good progress after change to new diet $\quad \ldots \quad r \mid \begin{array}{lll}\cdots & \ldots & 4\end{array}$ Died

A survey of these cases showed the following advantages and disadvantages of the Bircher-Benner diet. 


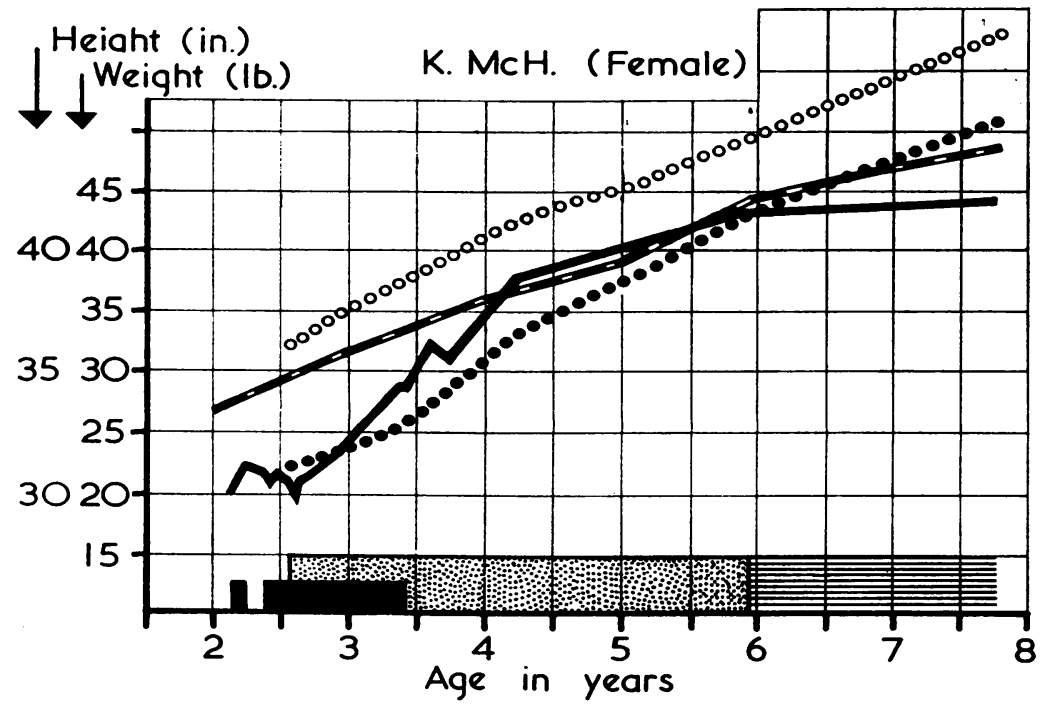

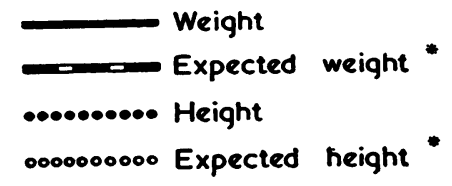

Period in hospital

On Bircher-Benner diet

QIACA On Fonconi-Dillistone diet

Change-over to full diet

* The standard height and weight charts are compiled from the following sources :

(1) Meredith, H. V. (1935). Univ. lowa Stud. Child Welf, 11, No. 2.
Boynton, B. (1936). Univ. Iowa Stud. Child

(3) O'Brien, R: Girshick M.A and Hunt, E. P. (1941) R., Girshick, M.A. and Hunt, E. P.

Publ. 366 .

Fig. 1.

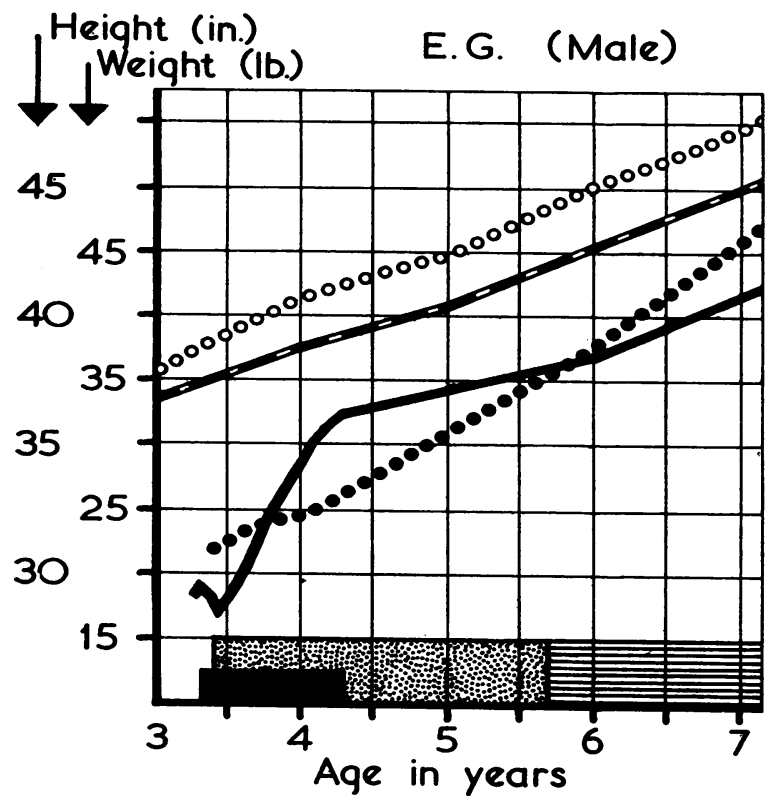

FIG. 2.

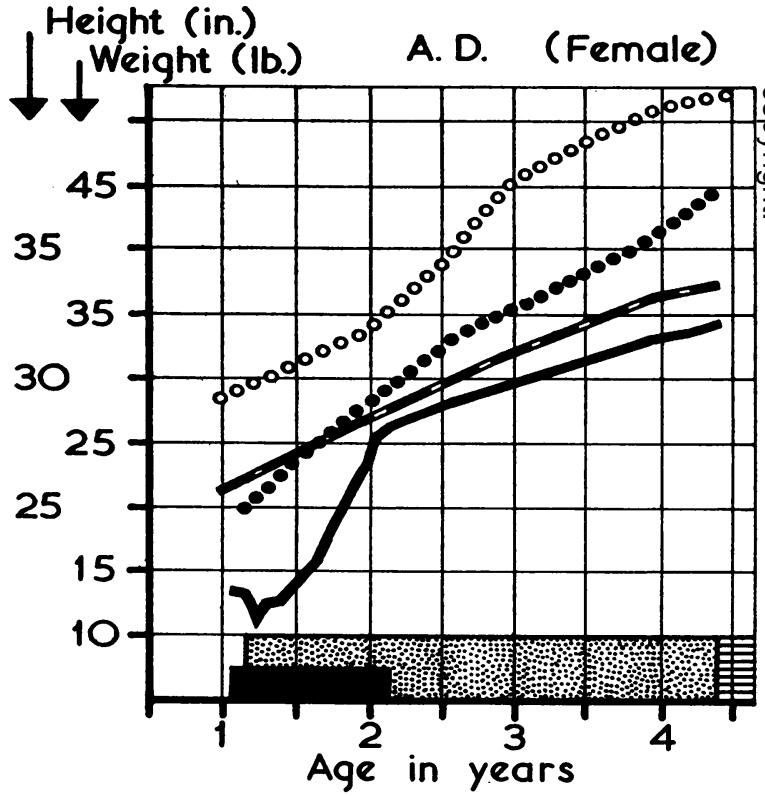

FIG. 3. 


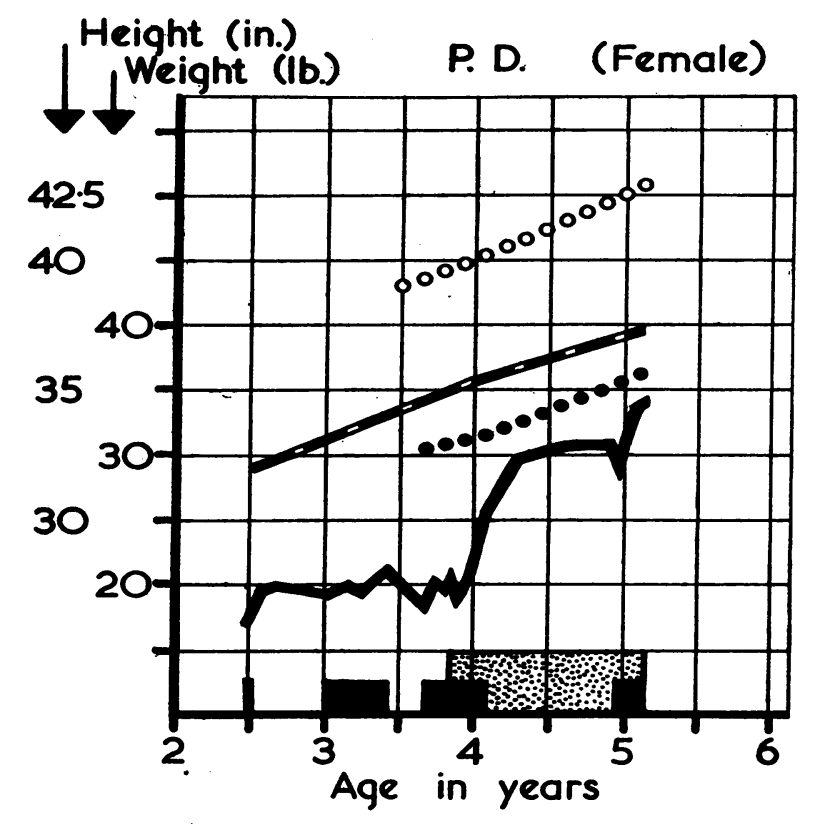

FIg. 4.

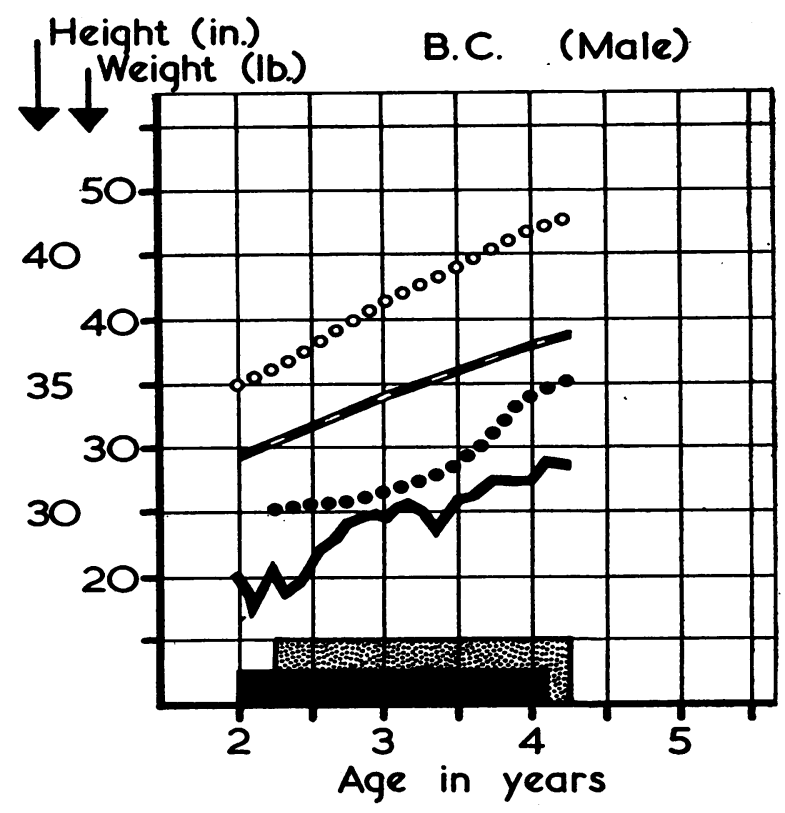

FIG. 6.

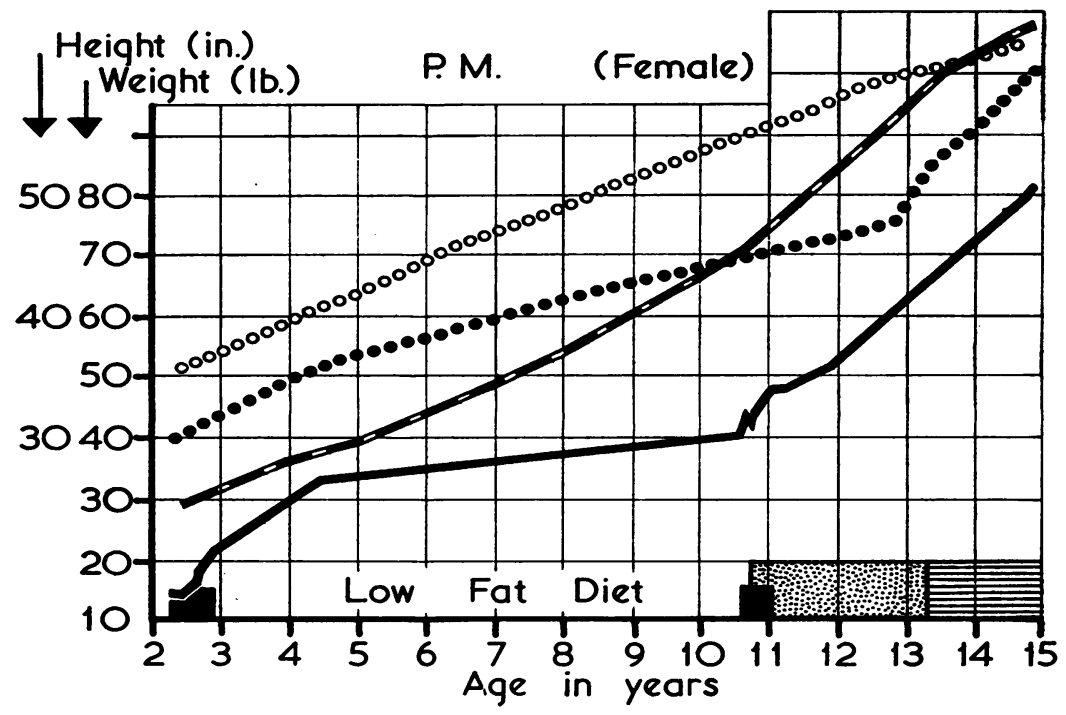

FIG. 5. 


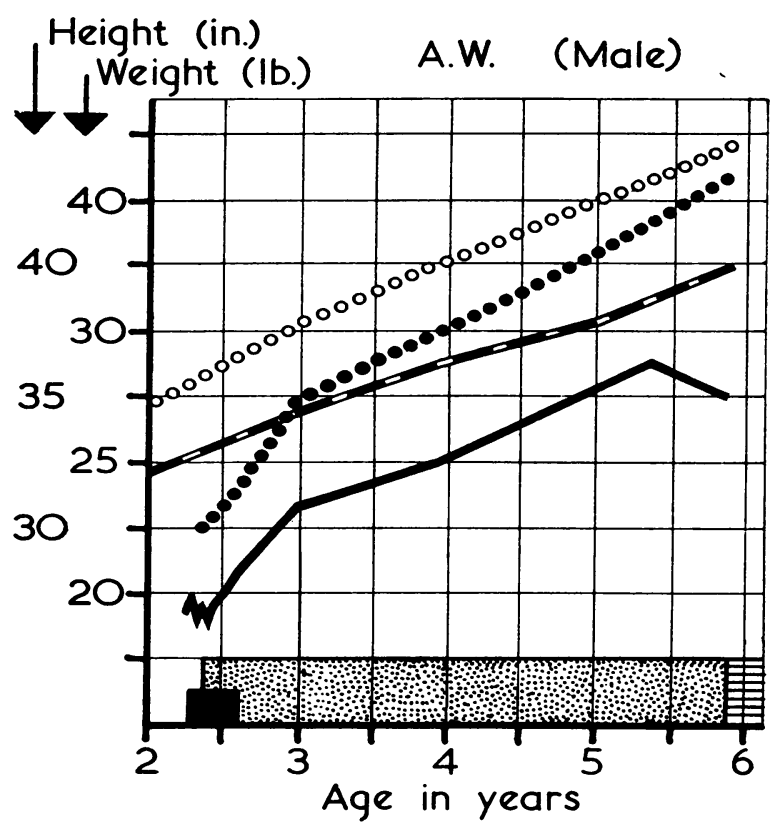

FIG. 7.

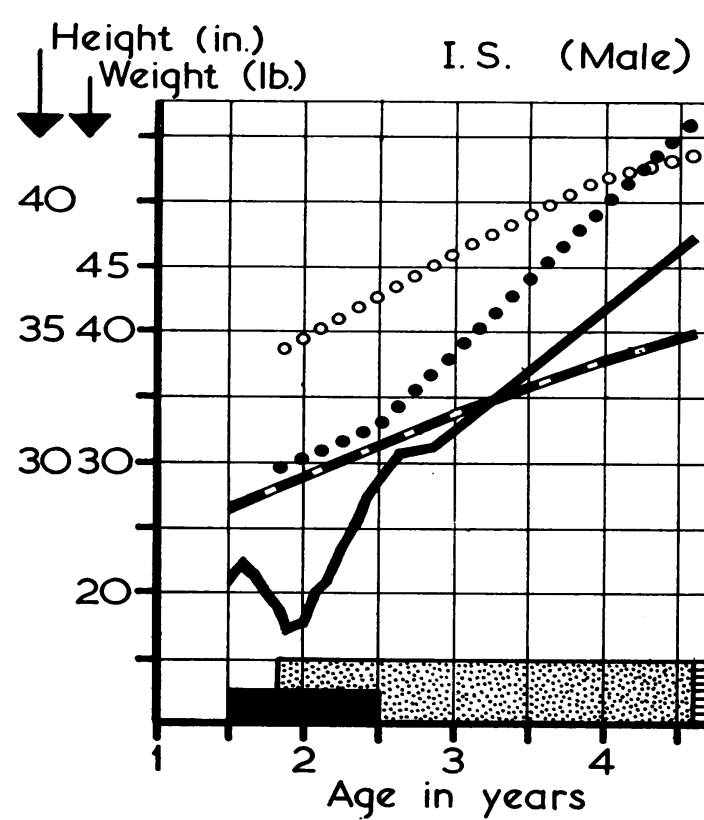

FIG. 8.

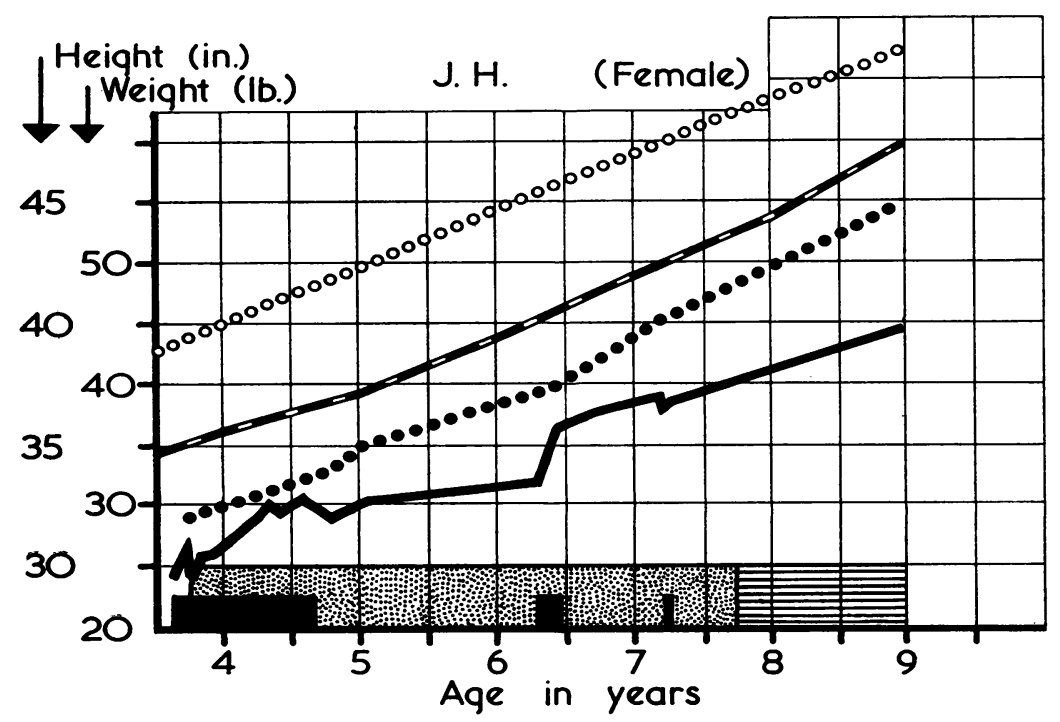

FIG. 9. 


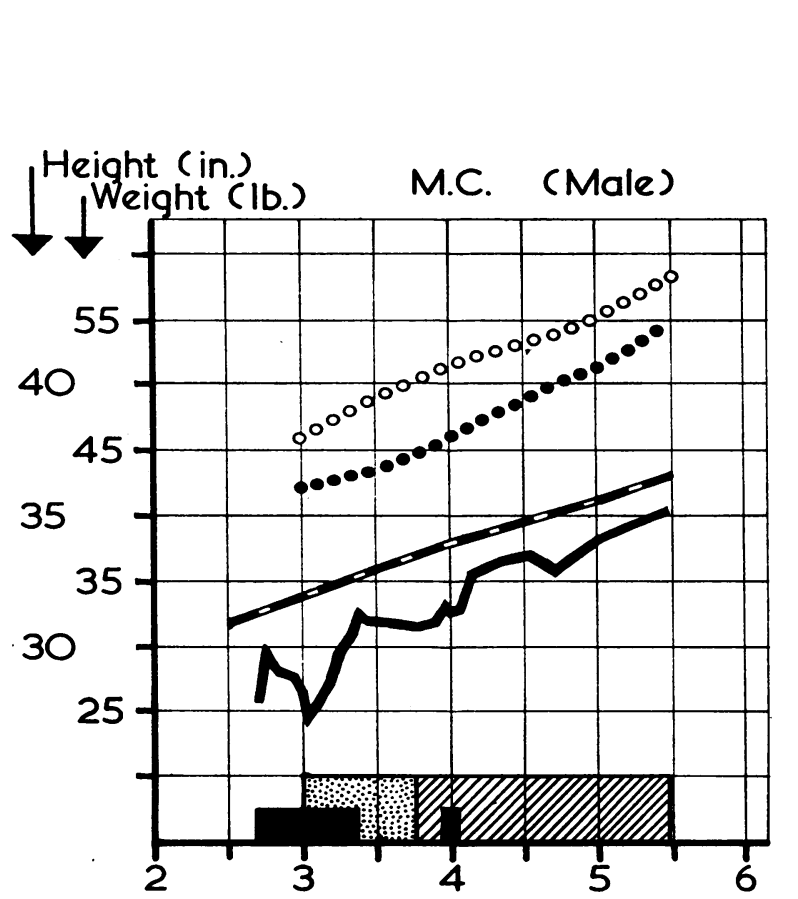

Age in years

FIG. 10.

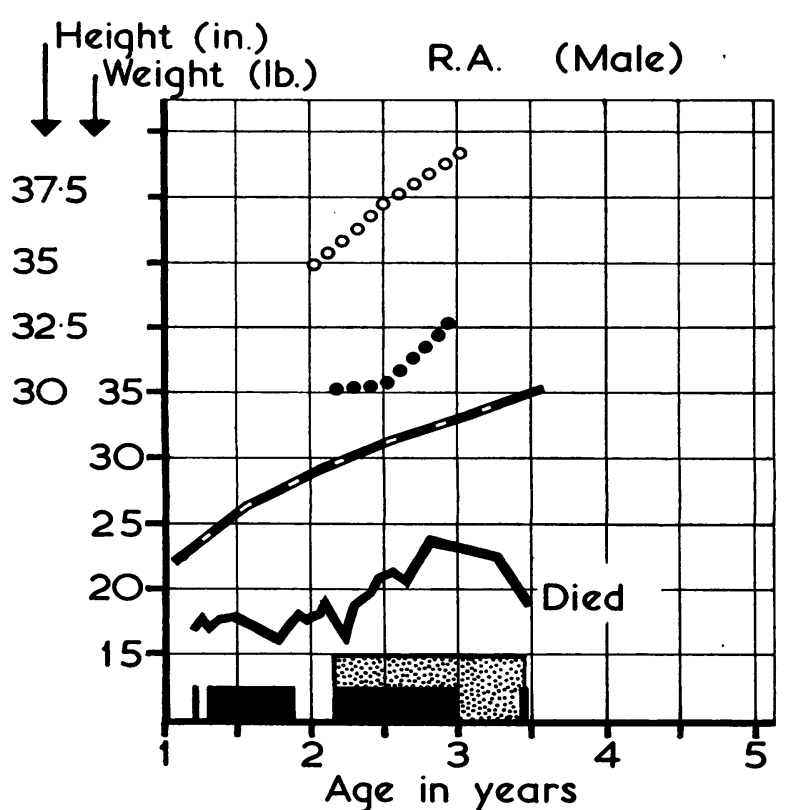

Age in years

FIG. 12.

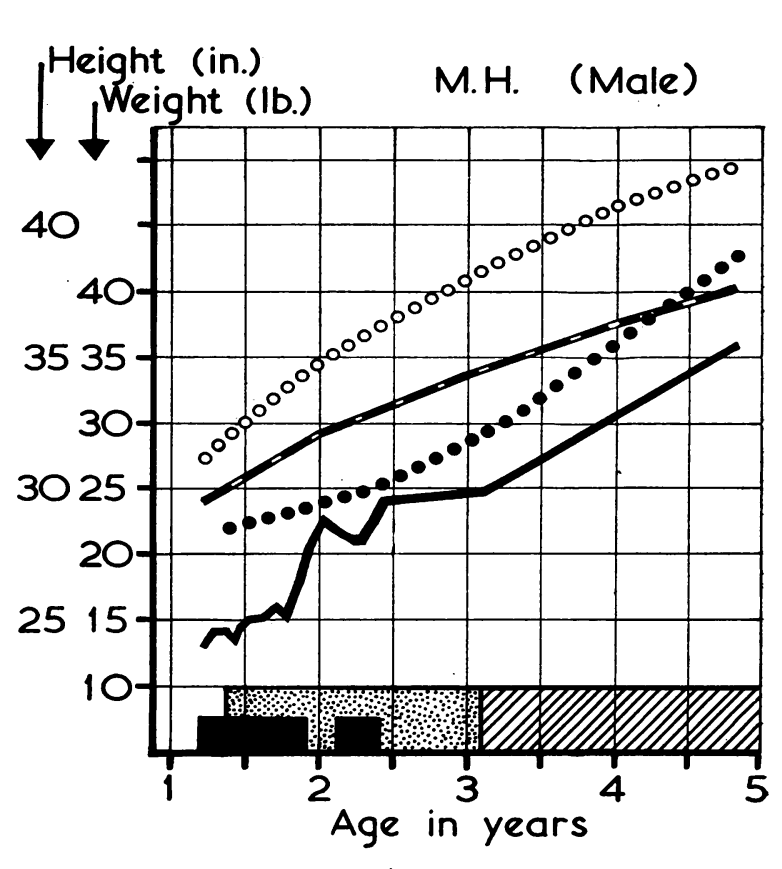

FIG. 11.

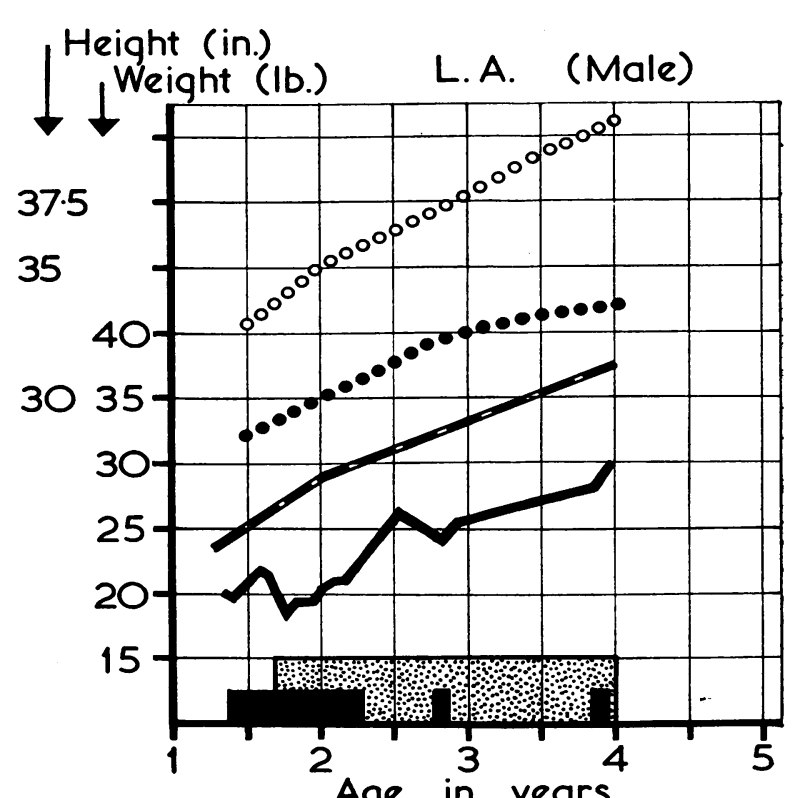

Age in years

Fig. 13.

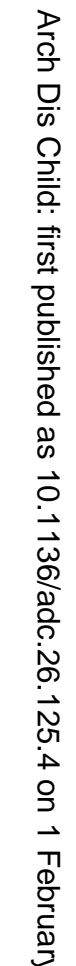




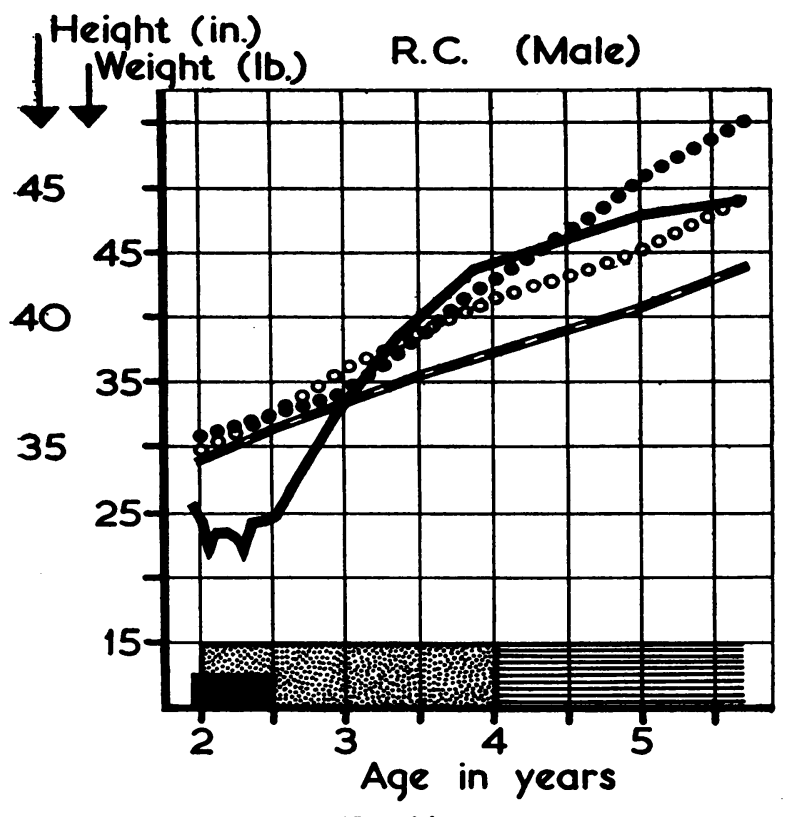

FIG. 14.

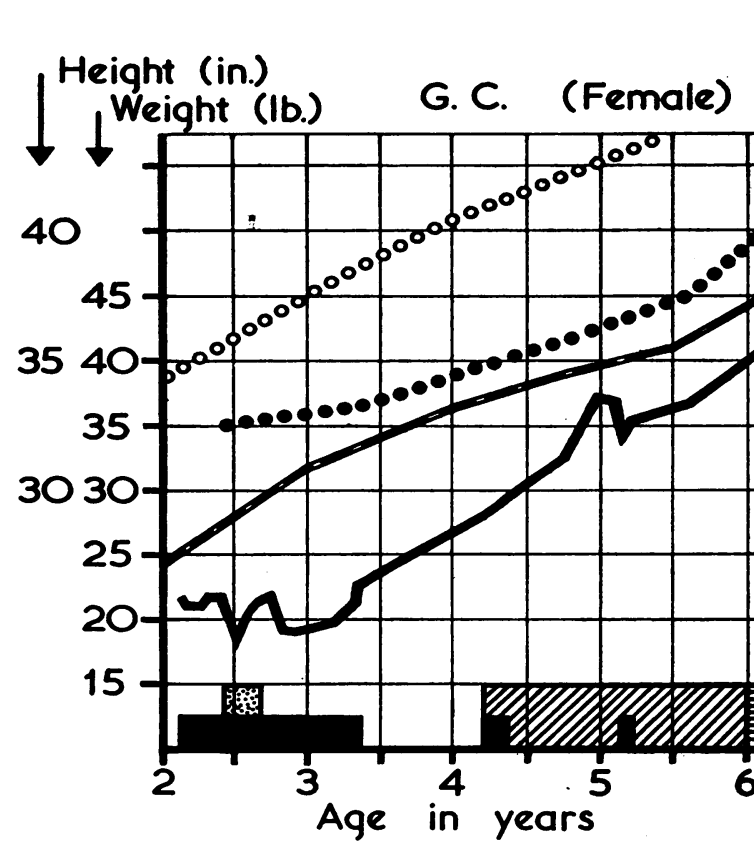

FIG. 18.

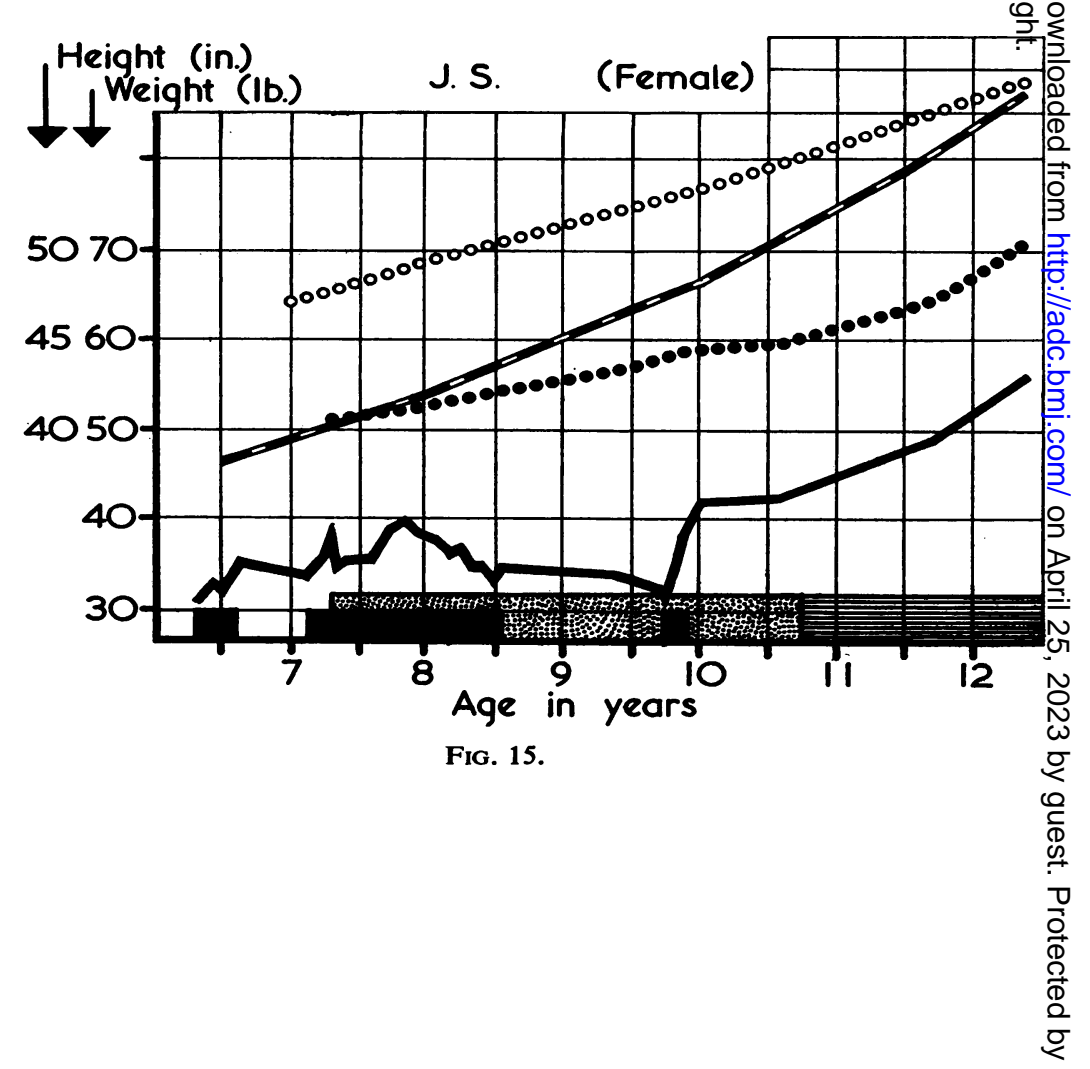




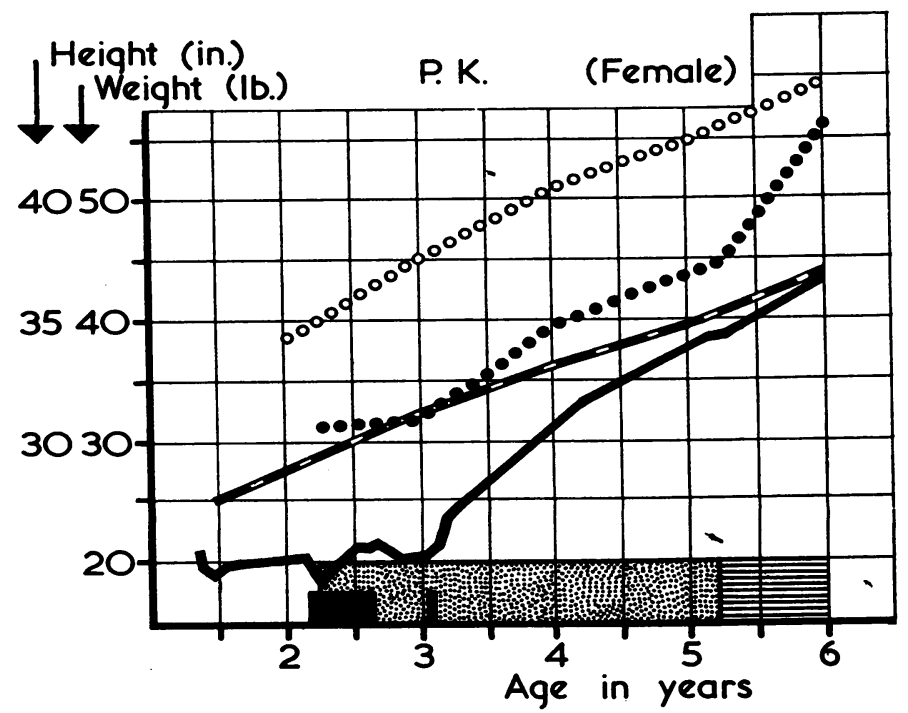

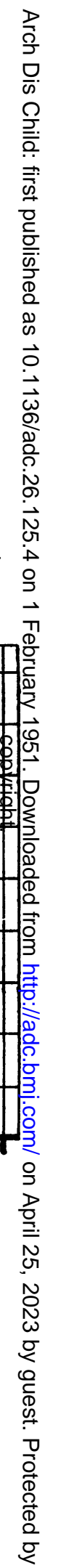

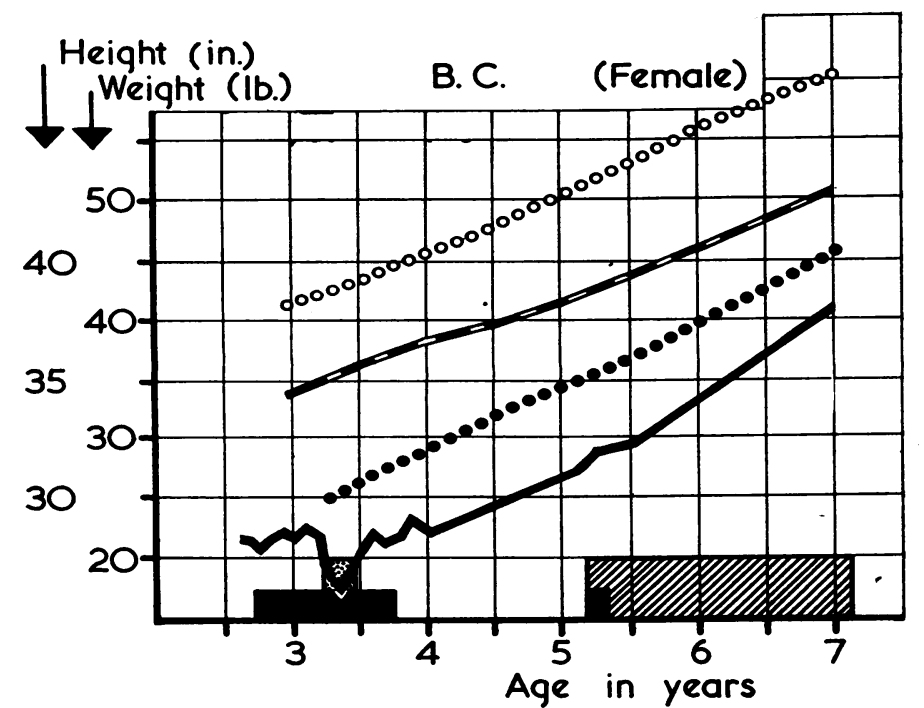

FIG. 17.

FIG. 16. 
Advantages. Control of the distension and of the fermenting and loose stools is rapid and certain. This in turn improves the temper and well-being of the patient. The stools become chemically normal. The diet provides an easily assimilable supply of fat, carbohydrate, and protein.

Disadvantages. Initial semi-starvation is too prolonged, leading to an unnecessary degree of collapse. The introduction of protein is too slow, leading to low plasma protein levels and oedema and in three cases delaying growth; the addition of animal protein is followed by a marked improvement. In fairness it must be admitted that if the child really eats all the diet the mixture of vegetable proteins and the small allowance of animal proteins is, in fact, sufficient in most cases for normal growth. The supply of vitamin $D$ is inadequate.

The diet is complicated, difficult to prepare, and expensive, and many children tire of its large bulk.

\section{The New Diet}

As the disadvantages of the Bircher-Benner diet became obvious, a modified diet similar to that used by Professor Fanconi (1937-38) was evolved (Appendix 2). This diet is divided into four stages, the first two being given wholly in hospital.

The duration of stage $I$ is not longer than six to ten days and may be called a 'starvation' phase, providing only 920 calories as against an average of roughly 1,200 calories for an infant of 1 to 2 years of age. It leads to clearing the bowel of its unhealthy contents. Usually a distinct improvement in the temperament of the child and a reduction of abdominal distension is noticeable.

Stage II is maintained roughly for a period of two weeks. Appetite usually improves, and the stools become fewer, less bulky, better coloured, and much less offensive.

Stage III begins in hospital and is continued at home, and may need to be maintained for six to nine months.

The transition to stage IV and onwards to a normal diet is by gradual experimental additions, guided by the tolerance shown by the child's appetite, digestion, and character of the stools. It is at this stage that starch-containing foods are introduced for the first time. Intercurrent infections, mainly respiratory, or intolerance to a particular foodstuff, may necessitate a halt or a regression in the progress of the dietary additions. The necessary vitamin needs are provided in the scheme as outlined.

Six new cases have so far been treated on this diet, and followed up for a period of two to three years. The records of their gain in weight and height compared with the expected average are given in Figs. 20-25. Also four of the cases not doing well on the Bircher-Benner diet were changed over to the appropriate stage of this diet (Figs. 10, $11,17,18)$. All these cases have so far shown no oedema, and plasma protein levels, when estimated, have been normal.

\section{Comment}

The diet is usually taken willingly, and the mothers do not complain of its being a trouble to prepare after one or more demonstrations by the hospital dietitian.

The period spent in hospital by the patient is comparatively short, and in most cases he should be back at home on stage III diet within two months of starting treatment. This has obvious advantages as these children so quickly become self-centred and temperamental in hospital and are constantly exposed to the risk of intercurrent infection.

It has been found possible to restore these children to a normal diet mostly within two years, but in two of the cases it would appear that this change was carried out too quickly.

The cost of this diet is not excessive. When special items are obtained through hospitals or clinics the cost has been thus estimated.*

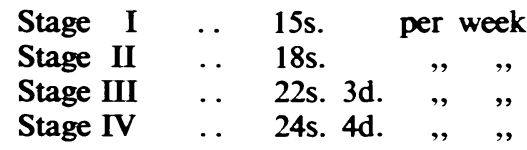

TABLE 2

Results on New Diet

\begin{tabular}{|c|c|c|c|}
\hline \multicolumn{2}{|c|}{$\begin{array}{l}\text { Intermediate } \\
\text { Period }\end{array}$} & \multirow{2}{*}{$\frac{\text { Late Period }}{4}$} & \multirow{2}{*}{$\frac{\text { Figs. }}{22,23,24,25}$} \\
\hline Good & 6 & & \\
\hline Moderate & $\mathbf{0}$ & $\begin{array}{l}2 \\
\text { (Progress not so good } \\
\text { on a normal diet) }\end{array}$ & 20,21 \\
\hline
\end{tabular}

\section{Summary}

A therapeutic trial is described of 19 cases of the coeliac affection treated with the fruit and vegetable diet of Bircher-Benner and followed up for a period of three to six years. Of the 19 patients only nine successfully followed the original regime and have done well. The disadvantages of this diet are outlined, the chief one being the relative shortage of first class protein, leading in many cases to hypoproteinaemia and oedema.

Arising from this trial a new four-stage diet was

- Estimate by Miss Dillistone, Dietitian to The Hospital for Sick Children, Great Ormond Street, London. 


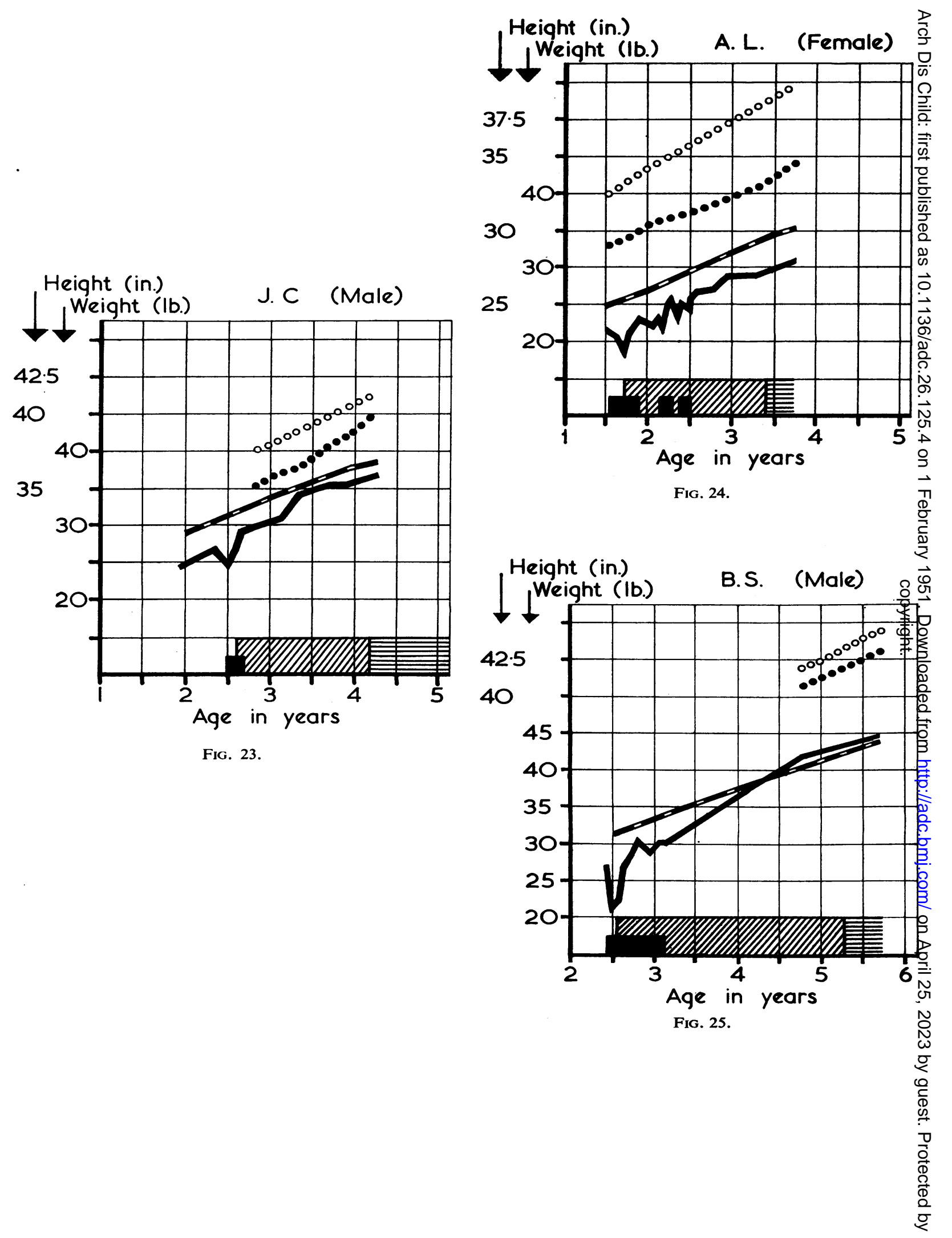


evolved and is described, being a modification of that first used by Fanconi. Six new and four old cases have been treated with this diet and followed up for a period of two to three years, with results which are encouraging so far.

We wish to acknowledge our thanks to Dr. R. Elgood and Dr. D. Cruickshank for their detailed progress records in cases 1-19, to Mrs. C. Loewenfeld for her constant advice on the Bircher-Benner diets, and to
Miss F. Dillistone for her help and advice with the new diet.

REFERENCES

Bircher-Benner, M. (1935). ' Kinderernährung.' Zurich. Fanconi, G. (1930). Klin. Wschr., 9, 553.

- (1937-8). Maandschr. Kindergeneesk., 7, 135.

Feer, E. (1929). Schweiz. med. Wschr., 10, 18.

Garrod, A. E., Batten, F. E., and Thursfield, H. (1947). 'Diseases of Children,' 4th ed. London.

May, C. D., McCreary, J.' F., and Blackfan, K. D. (1942). J. Pediat., 21, 289.

\section{A P P E N D I X I}

The Bircher-Bemer Regime

(MODIFIED BY MRs. C. LOEWENFELD)

Nutcream: $\quad$ Nut emulsion (C. 23 16, P. 21 77 , F. 51-27).

Enervyte: Unprocessed wheat germ.

Apple juice: Pure, unfermented, unsweetened apple juice in bottles.

Rose hip tea: An infusion made by simmering dried soaked rose hips (pods and pips) for 20 to 30 mins.

Raw fruit porridge: $7 \frac{1}{2}-15$ g. fine or medium soaked (Bircher Muesli) oatmeal mixed with lemon juice, honey, nutcream (prescribed) or milk and 2-5 oz. (60-150 g.) grated apple or mashed fruit (sieved at the beginning).

Rice gruel:

(or other cereal gruels)

Fruit juices:

Vegetable juices: Combined from various vegetables spoons rice (oats, wheat, barley) to 1 pint $(600 \mathrm{c} . \mathrm{cm}$.) water, boiled for $20-60$ mins.

Combined from various fruit in season, freshly extracted and sieved.

in season, such as carrots and tomatoes as a basis, with smaller quantities of beetroot, celery, lettuce, spinach, brussels sprouts, cabbage, onion, leek, and herbs added.

Children from the age of 16-18 months onwards: Four feeds per day at ordinary meal times.

Children under 16 months and below average weight: Four-hourly feeds are given and the juices and nutcream supplemented by rice gruel to make up the desired quantity according to the expected weight for the child's age.

All feeds are sweetened with honey to taste.

According to the age and digestive capacity of the child, fresh fruit and uncooked vegetables are given in the form of juice, puree, or grated or chopped in salads, or the fruit may be given whole.

The prescribed quantity of nutcream per meal is distributed over the various uncooked fruit and vegetable dishes of this meal, according to the child's liking.

All freshly expressed undiluted fruit and vegetable juices with or without nutcream are considered as food, not drink, and are fed with a spoon.

Diet Sheet for Stage I (Raw Day: 3-5 Days)

\begin{tabular}{|c|c|c|c|c|c|}
\hline Time & & Intake (oz) & Foods & Protein (g.) & Calories \\
\hline 7 a.m. & . & $\begin{array}{l}5 \\
2 \\
\frac{1}{2}\end{array}$ & $\begin{array}{l}\text { Rose hip tea } \\
\text { Fruit juice } \\
\text { Honey }\end{array}$ & 0.5 & $\begin{array}{r}2 \\
20 \\
43\end{array}$ \\
\hline 9.30 a.m. & . & $\begin{array}{l}6 \\
2 \\
5 \\
2\end{array}$ & $\begin{array}{l}\text { Fruit juice } \\
\text { Tomato puree (sieved) } \\
\text { Rose hip tea } \\
\text { Honey }\end{array}$ & $\begin{array}{l}0.6 \\
0.5\end{array}$ & $\begin{array}{r}60 \\
9 \\
2 \\
172\end{array}$ \\
\hline 12.30 p.m. & . & $\begin{array}{l}5 \\
4 \\
4 \\
2\end{array}$ & $\begin{array}{l}\text { Fruit juice } \\
\text { Vegetable juice } \\
\text { Apple juice drink } \\
\text { Honey }\end{array}$ & $1 \cdot 8$ & $\begin{array}{r}50 \\
24 \\
60 \\
172\end{array}$ \\
\hline \multirow[t]{2}{*}{6 p.m. } & $\cdots$ & $\begin{array}{l}8 \\
5 \\
2\end{array}$ & $\begin{array}{l}\text { Fruit juice } \\
\text { Rose hip tea } \\
\text { Honey }\end{array}$ & 0.5 & $\begin{array}{r}80 \\
2 \\
172\end{array}$ \\
\hline & & & & 3.9 & 868 \\
\hline
\end{tabular}




\begin{tabular}{|c|c|c|c|c|c|c|c|}
\hline & \multirow{2}{*}{$\begin{array}{c}\text { Raw Day } \\
\begin{array}{l}\text { Intake } \\
(\mathrm{oz})\end{array}\end{array}$} & \multirow{2}{*}{$\begin{array}{c}\text { Cooked Day } \\
\begin{array}{l}\text { Intake } \\
(\text { oz. })\end{array}\end{array}$} & \multirow[b]{2}{*}{ Foods } & \multicolumn{2}{|c|}{ Raw Day } & \multicolumn{2}{|c|}{ Cooked Day } \\
\hline & & & & $\begin{array}{l}\text { Protein } \\
\text { (g.) }\end{array}$ & Calories & $\begin{array}{c}\text { Protein } \\
\text { (g.) }\end{array}$ & Calories \\
\hline 7 a.m. & $\begin{array}{l}5 \\
2 \\
\frac{1}{2}\end{array}$ & $\begin{array}{l}5 \\
2 \\
\frac{1}{2}\end{array}$ & $\begin{array}{l}\text { Rose hip tea } \\
\text { Fruit juice } \\
\text { Honey }\end{array}$ & 0.5 & $\begin{array}{r}2 \\
20 \\
43\end{array}$ & 0.5 & $\begin{array}{r}2 \\
20 \\
43\end{array}$ \\
\hline 9.30 a.m. & $\begin{array}{l}6 \\
2 \\
5 \\
\frac{1}{4} \\
2^{\frac{1}{4}}\end{array}$ & $\begin{array}{l}6 \\
2 \\
5 \\
\frac{1}{\frac{1}{3}} \\
2^{\frac{3}{4}}\end{array}$ & $\begin{array}{l}\text { Fruit juice } \\
\text { Tomato puree (sieved) } \\
\text { Rose hip tea } \\
\text { Enervyte } \\
\text { Nutcream } \\
\text { Honey }\end{array}$ & $\begin{array}{l}0 \cdot 6 \\
0 \cdot 5 \\
0 \cdot 8 \\
4 \cdot 8\end{array}$ & $\begin{array}{r}60 \\
9 \\
2 \\
24 \\
144 \\
172\end{array}$ & $\begin{array}{l}0 \cdot 6 \\
0 \cdot 5 \\
0 \cdot 8 \\
4 \cdot 8\end{array}$ & $\begin{array}{r}60 \\
9 \\
2 \\
24 \\
144 \\
172\end{array}$ \\
\hline 12.30 p.m. & $\begin{array}{l}5 \\
4 \\
2 \\
4 \\
1 \\
1 \frac{1}{2}\end{array}$ & $\begin{array}{l}4 \\
3 \\
2 \\
4 \\
3 \\
1 \\
6\end{array}$ & $\begin{array}{l}\text { Fruit juice } \\
\text { Vegetable juice } \\
\text { Tomato puree (sieved) } \\
\text { Apple juice drink } \\
\text { Nutcream } \\
\text { Honey } \\
\text { Cooked vegetable soup with } \\
\text { soya flour }\end{array}$ & $\begin{array}{l}1 \cdot 8 \\
0 \cdot 6 \\
6 \cdot 4\end{array}$ & $\begin{array}{r}50 \\
24 \\
9 \\
60 \\
192 \\
129\end{array}$ & $\begin{array}{l}1 \cdot 3 \\
0.6 \\
4 \cdot 8 \\
9 \cdot 0\end{array}$ & $\begin{array}{r}40 \\
18 \\
9 \\
60 \\
144 \\
86 \\
120\end{array}$ \\
\hline 6 p.m. & $\begin{array}{c}6 \\
5 \\
\frac{1}{2} \\
\frac{3}{4}\end{array}$ & $\begin{array}{c}6 \\
5 \\
1 \\
\frac{1}{3} \\
2\end{array}$ & $\begin{array}{l}\text { Fruit juice } \\
\text { Rose hip tea } \\
\text { Enervyte } \\
\text { Nutcream } \\
\text { Honey }\end{array}$ & $\begin{array}{l}0 \cdot 5 \\
0 \cdot 8 \\
4 \cdot 8\end{array}$ & $\begin{array}{r}60 \\
2 \\
24 \\
144 \\
172\end{array}$ & $\begin{array}{l}0 \cdot 5 \\
0 \cdot 8 \\
4 \cdot 8\end{array}$ & $\begin{array}{r}60 \\
2 \\
24 \\
144 \\
172\end{array}$ \\
\hline & & & & $22 \cdot 1$ & 1,342 & $29 \cdot 0$ & 1,355 \\
\hline
\end{tabular}

Diet Sheet for Stage III (1-12 Months)

\begin{tabular}{|c|c|c|c|c|c|c|c|}
\hline & \multirow{2}{*}{$\begin{array}{c}\text { Raw Day } \\
\begin{array}{c}\text { Intake } \\
\text { (oz.) }\end{array}\end{array}$} & \multirow{2}{*}{ 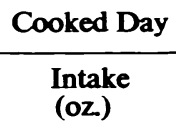 } & \multirow[b]{2}{*}{ Foods } & \multicolumn{2}{|c|}{ Raw Day } & \multicolumn{2}{|c|}{ Cooked Day } \\
\hline & & & & $\begin{array}{l}\text { Protein } \\
\text { (g.) }\end{array}$ & Calories & $\begin{array}{l}\text { Protein } \\
\text { (g.) }\end{array}$ & Calories \\
\hline 7 a.m. & $\begin{array}{l}5 \\
2 \\
\frac{1}{2}\end{array}$ & $\begin{array}{l}5 \\
2 \\
\frac{1}{2}\end{array}$ & $\begin{array}{l}\text { Rose hip tea } \\
\text { Fruit juice } \\
\text { Honey }\end{array}$ & 0.5 & $\begin{array}{r}2 \\
20 \\
43\end{array}$ & 0.5 & $\begin{array}{r}2 \\
20 \\
43\end{array}$ \\
\hline 9.30 a.m. & $\begin{array}{l}4 \\
4 \\
5 \\
\frac{1}{3} \\
2 \\
2\end{array}$ & $\begin{array}{l}4 \\
4 \\
5 \\
4 \\
\frac{1}{3} \\
2\end{array}$ & $\begin{array}{l}\text { Raw fruit porridge(Muesli) } \\
\text { Fruit juice } \\
\text { Rose hip tea } \\
\text { Enervyte } \\
\text { Nutcream } \\
\text { Honey }\end{array}$ & $\begin{array}{l}3 \cdot 5 \\
0 \cdot 5 \\
0 \cdot 8 \\
4 \cdot 8\end{array}$ & $\begin{array}{r}100 \\
40 \\
2 \\
24 \\
144 \\
172\end{array}$ & $\begin{array}{l}3 \cdot 5 \\
0 \cdot 5 \\
0 \cdot 8 \\
4 \cdot 8\end{array}$ & $\begin{array}{c}100 \\
40 \\
2 \\
24 \\
144 \\
172\end{array}$ \\
\hline$\overline{12.30 \text { p.m. }}$ & $\begin{array}{c}2 \\
4 \\
3 \\
4 \\
\frac{3}{2} \\
1 \\
1\end{array}$ & $\begin{array}{l}2 \\
3 \\
2 \\
4 \\
\frac{1}{2} \\
1^{\frac{1}{2}} \\
6 \\
2\end{array}$ & $\left.\begin{array}{l}\text { Grated apple (or whole fruit) } \\
\text { Vegetable juice (or puree) } \\
\text { Fruit juice } \\
\text { Apple juice drink } \\
\text { Nutcream } \\
\text { Cottage cheese } \\
\text { Honey } \\
\text { Thick vegetable soup } \\
\text { (or puree or stew) } \\
\text { Spinach puree }\end{array}\right\}$ & $\begin{array}{l}1 \cdot 8 \\
4 \cdot 8 \\
4 \cdot 5\end{array}$ & $\begin{array}{r}20 \\
24 \\
30 \\
60 \\
144 \\
68 \\
86\end{array}$ & $\begin{array}{l}1 \cdot 3 \\
\\
3 \cdot 2 \\
4 \cdot 5 \\
\\
9 \cdot 0 \\
4 \cdot 2\end{array}$ & $\begin{array}{r}20 \\
18 \\
20 \\
60 \\
96 \\
68 \\
86 \\
120 \\
60\end{array}$ \\
\hline 6 p.m. & $\begin{array}{c}4 \\
4 \\
5 \\
\frac{1}{4} \\
2\end{array}$ & $\begin{array}{c}4 \\
4 \\
5 \\
\frac{1}{4} \\
2\end{array}$ & $\begin{array}{l}\text { Raw fruit porridge (Muesli) } \\
\text { Fruit juice } \\
\text { Rose hip tea } \\
\text { Enervyte } \\
\text { Nutcream } \\
\text { Honey }\end{array}$ & $\begin{array}{l}3 \cdot 5 \\
0 \cdot 5 \\
0 \cdot 8 \\
4 \cdot 8\end{array}$ & $\begin{array}{r}100 \\
40 \\
2 \\
24 \\
144 \\
172\end{array}$ & $\begin{array}{l}3 \cdot 5 \\
0 \cdot 5 \\
0 \cdot 8 \\
4 \cdot 8\end{array}$ & $\begin{array}{r}100 \\
40 \\
2 \\
24 \\
144 \\
172\end{array}$ \\
\hline & & & & $30 \cdot 8$ & 1,461 & $41 \cdot 9$ & 1,577 \\
\hline
\end{tabular}


Diet Shieet for Stage IV (Until Dischange from Hosptial)

\begin{tabular}{|c|c|c|c|c|c|c|c|}
\hline \multirow{2}{*}{ Time } & \multirow{2}{*}{$\frac{\text { Raw Day }}{\begin{array}{c}\text { Intake } \\
(\text { oz) }\end{array}}$} & \multirow{2}{*}{$\begin{array}{c}\text { Cooked Day } \\
\begin{array}{c}\text { Intake } \\
\text { (oz) }\end{array}\end{array}$} & \multirow[b]{2}{*}{ Foods } & \multicolumn{2}{|c|}{ Raw Day } & \multicolumn{2}{|c|}{ Cooked Day } \\
\hline & & & & $\begin{array}{l}\text { Protein } \\
\text { (g) }\end{array}$ & Calories & $\begin{array}{l}\text { Protein } \\
\text { (g.) }\end{array}$ & Calories \\
\hline 7 a.m. & $\begin{array}{l}5 \\
2 \\
\frac{1}{2}\end{array}$ & $\begin{array}{l}5 \\
2 \\
\frac{1}{2}\end{array}$ & $\begin{array}{l}\text { Rose hip tea } \\
\text { Fruit juice } \\
\text { Honey }\end{array}$ & 0.5 & $\begin{array}{r}2 \\
20 \\
43\end{array}$ & 0.5 & $\begin{array}{r}2 \\
20 \\
43\end{array}$ \\
\hline 8-9 a.m. & $\begin{array}{c}2 \\
\frac{1}{3} \\
2\end{array}$ & $\begin{array}{c}5 \\
3 \\
1 \\
1 \\
2 \\
2 \\
\frac{1}{2} \\
2^{\frac{1}{2}}\end{array}$ & $\begin{array}{l}\text { Raw fruit porridge (Muesli) } \\
\text { Whole fruit (or grated } \\
\text { apple or juice) } \\
\text { Wholemeal bread with } \\
\text { butter (or nutcream } \\
\text { spread) } \\
\text { Milk } \\
\text { Enervyte } \\
\text { Nutcream } \\
\text { Honey }\end{array}$ & $\begin{array}{l}2 \cdot 0 \\
0 \cdot 8 \\
4 \cdot 8\end{array}$ & $\begin{array}{r}34 \\
24 \\
144 \\
172\end{array}$ & $\begin{array}{l}\cdot 4 \\
2 \cdot 4 \\
\\
2 \cdot 0 \\
0 \cdot 8 \\
3 \cdot 2\end{array}$ & $\begin{array}{r}125 \\
30 \\
70 \\
50 \\
34 \\
24 \\
96 \\
172\end{array}$ \\
\hline$\overline{12.30 \text { p.m. }}$ & $\begin{array}{l}3 \\
4 \\
4\end{array}$ & $\begin{array}{l}3 \\
4 \\
4 \\
8 \\
3 \\
3 \\
\\
\end{array}$ & $\begin{array}{l}\text { Whole fruit (or purce or } \\
\text { juice) } \\
\text { Mixed dressed salad (or } \\
\text { vegetable juice) } \\
\text { Apple juice drink } \\
\text { Thick vegtable soup (or } \\
\text { purce or stew), with soya } \\
\text { four (or rice, barley, } \\
\text { wheat, etc) } \\
\text { Spinach puree with soya } \\
\text { flour and mashed potatoes. } \\
1 \text { egg per week (6.8 g. } \\
\text { protein, } 80 \text { Cal.) } \\
\text { Cottage cheese } \\
\text { Nutream } \\
\text { Sweet made from fruit and } \\
\text { nutcream (or cottage } \\
\text { cheese) (or }\end{array}$ & $1 \cdot 8$ & $\begin{array}{r}30 \\
180 \\
60\end{array}$ & $\begin{array}{r}12 \cdot 0 \\
6 \cdot 5 \\
4 \cdot 5 \\
4 \cdot 5\end{array}$ & $\begin{array}{r}200 \\
100 \\
68\end{array}$ \\
\hline 6.30 p.m. & $\begin{array}{c}5 \\
\frac{1}{3} \\
1\end{array}$ & $\begin{array}{c}5 \\
3 \\
1 \\
1 \\
2 \\
1 \\
1 \\
1 \\
1\end{array}$ & $\begin{array}{l}\text { Raw fruit porridge (Muesli) } \\
\text { Whole fruit (or grated apple } \\
\text { or juice) } \\
\text { Wholemeal bread with } \\
\text { butter (cottage cream or } \\
\text { - nutcream) } \\
\text { Milk } \\
\text { Rose hip tea } \\
\text { Enervyte } \\
\text { Nutcream } \\
\text { Cottage cheese } \\
\text { Honey }\end{array}$ & $\begin{array}{l}0 \cdot 5 \\
0 \cdot 8 \\
4 \cdot 8\end{array}$ & $\begin{array}{r}2 \\
24 \\
144 \\
86 \\
\end{array}$ & $\begin{array}{l}4 \cdot 4 \\
2 \cdot 4 \\
2 \cdot 0 \\
0 \cdot 8 \\
4 \cdot 5\end{array}$ & $\begin{array}{r}125 \\
30 \\
70 \\
50 \\
34 \\
24 \\
68 \\
86 \\
\end{array}$ \\
\hline
\end{tabular}

Weftiy Dietary Regme for Stage V (After DSCHARGE)

Monday Raw day (according to stage IV).

Tuesday Transitional day (according to stage III 'cooked day ').

Wednesday Cooked day with $1 \mathrm{cgg}$.

Thursday Cooked day with 1 oz grated cheese.

Friday Cooked day with $1 \mathrm{oz}$ grated cheese.

Saturday Cooked day with $1 \mathrm{oz}$. meat.

Sunday Cooked day with $1 \frac{1}{2}$ oz meat. 


\author{
Breakfast Raw fruit porridge (Muesli). \\ Whole fruit, some dried fruit. \\ 1-2 slices wholemeal bread with butter \\ and honey or nutcream or cottage \\ cheese. \\ 1 cup rose hip tea with honey and milk \\ or 2-4 oz. milk. \\ Mid-day meal Whole fresh fruit. \\ Mixed dressed salad. \\ Cooked vegetable dish with potatoes or \\ macaroni or rice with some protein \\ addition.
}

\section{Erample for 'Cooked Day'}

Mid-day meal Sweet from fresh or stewed fruit with

(cont.) cottage cheese or nutcream or top of the milk.

1 glass apple juice drink.

Evening meal Raw fruit porridge (Muesli).

Whole fruit, some dried fruit.

1-2 slices wholemeal bread with butter and honey or nutcream or cottage cheese and tomatoes.

1 cup rose hip tea with honey and milk or 2-4 oz. milk.

\section{A P P E N D I X I I \\ The New Diet}

The diet is arranged in four stages. Stage $I$ is a preliminary period of rest for the gastrointestinal tract and supplies fluid, protein, and carbohydrate in a predigested form. This period is from one to four days. Stage II follows and is continued for another four to six days. After the rest period appetite returns and stage III is begun; the calorie value at this stage may be increased by giving larger helpings of food allowed. Starch-containing foods are introduced into stage IV; these may be increased according to the ability of the child to hydrolyse and absorb starch.

The whole of the dietary regime contains a high amount of protein with moderate amounts of fat. The important feature is the choice of carbohydrates, which in the first three stages are selected from the non-starch-containing foods. A starch-free bread sold under the trade name of 'proferin' is now available, also a starch-free flour. Soya bean flour is also starch-free and may be used for the making of puddings and biscuits. Vitamin supplements are given separately.

VITAMIN

Preparations

StAGe I

Feeds given 4hourty: number of feeds 5. Amount given at cach feed 6 to $8 \mathrm{oz}$. Fruit juices sweetened with honey given between 10 a.m. and 2 p.m. and 2 p.m. and 6 p.m. feeds.

6 a.m

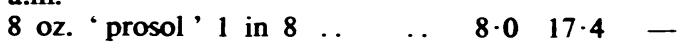

20 g. glucose $\quad . \quad \ldots \quad \ldots \quad 20.0 \quad-\quad$ -

10 a.m.

$\begin{array}{llllll}7 \text { oz. buttermilk } & \ldots & \ldots & 13 \cdot 2 & 8 \cdot 1 & 2 \cdot 5\end{array}$

20 g. glucose $\quad . \quad \ldots \quad \ldots \quad \ldots 20.0 \quad-\quad-$

2 p.m.

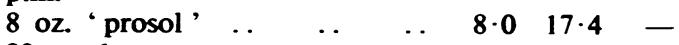

20 g. glucose $\quad \ldots \quad \ldots \quad \ldots 20.0 \quad-\quad-$

6 p.m.

$\begin{array}{lllllll}7 \mathrm{oz} \text {. buttermilk } & \ldots & \ldots & 13 \cdot 2 & 8 \cdot 1 & 2 \cdot 5\end{array}$

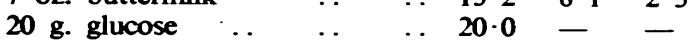

10 p.m.

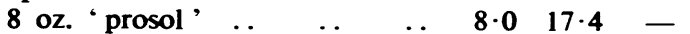

20 g. 'dextrimaltose' $\ldots \begin{array}{lllll}0 & \ldots & 20.0 & - & -\end{array}$

$150 \cdot 4 \quad 68 \cdot 4 \quad 5 \cdot 0$
DiET

VITAMmN Preparations

\section{Stage II}

Feeds given 4hourty; number of feeds 5 . Amount given at each feed 6 to 8 oz. Fruit juices sweetened with honey given between 10 a.m. and 2 p.m. and 2 p.m. and 6 p.m. feeds.

6 a.m.

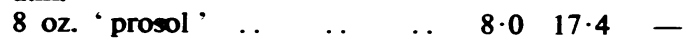

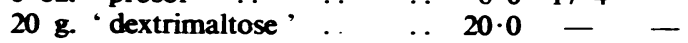

10 a.m.

7 oz. buttermilk

4 oz. banana puree

2 p.m.

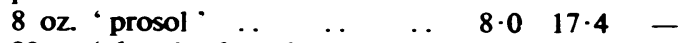

20 g. 'dextrimaltose'

p.m.

7 oz. buttermilk. .

4 oz. banana puree 10 p.m.

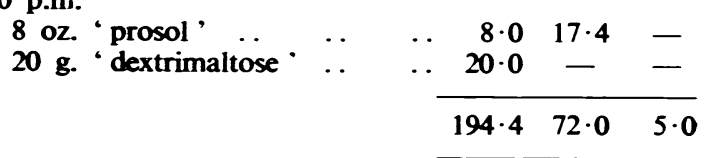




\section{Vitamin Preparations}

\section{Stages III AND IV}

Halibut liver oil, 10 drops daily. Ascorbic acid, $50 \mathrm{mg}$., when fresh juices are not availabte.

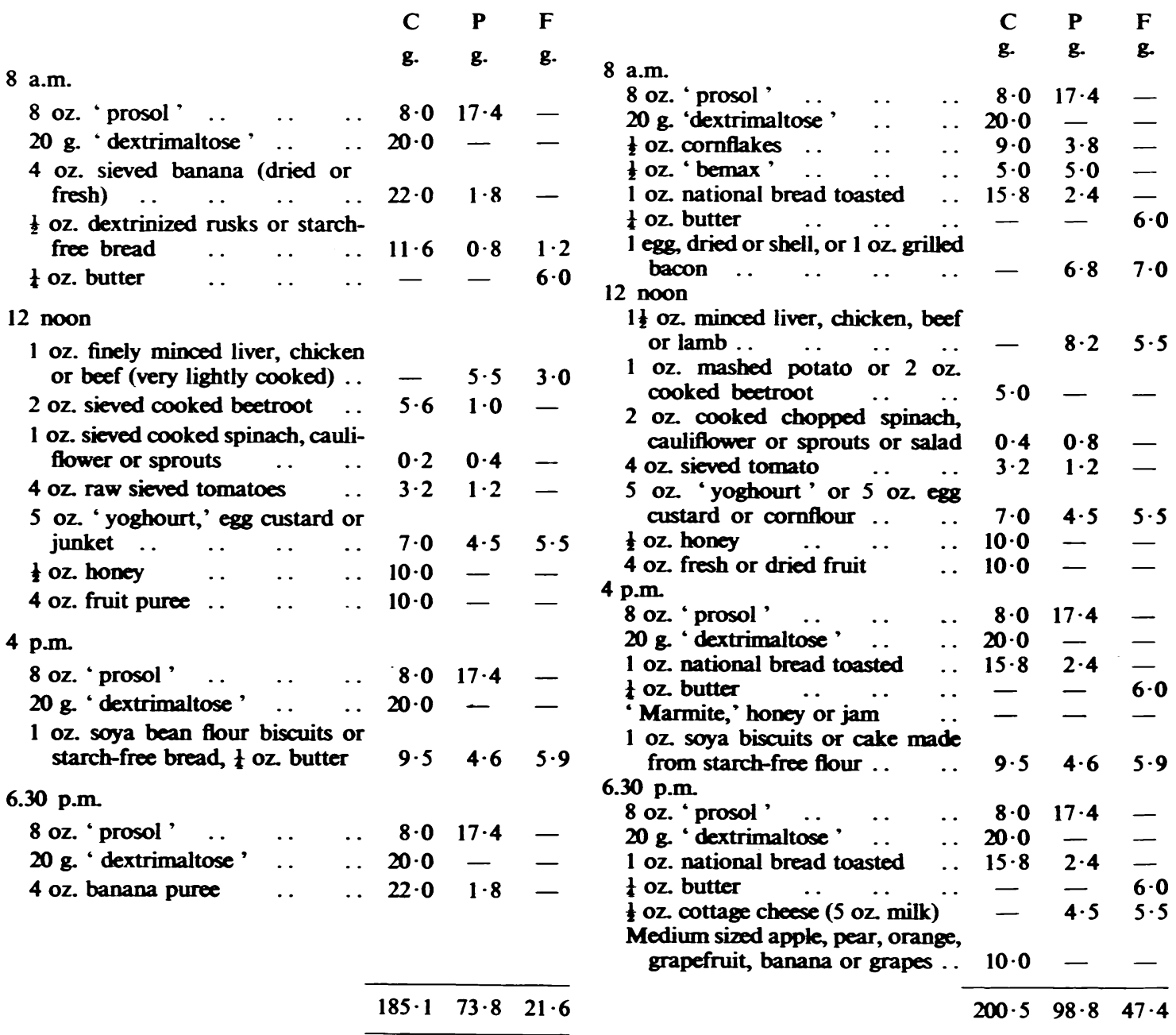

Total Calories 1,190

Total Calories 1,623 